Dr MILANA ŽIVANOVIĆ, naučni saradnik

Institut za noviju istoriju Srbije

Beograd, Republika Srbija

UDK 94:314.151.3(=161.1)(497.1)"1944/1945"(093.2)

milana.zivanovic@yahoo.com

930.85(=161.1)(497.1)"1944/1945"(093.2)

pregledni $\mathrm{rad} /$ review article

primljeno / received: 20. 1. 2020.

prihvaćeno / accepted: 20. 11. 2020.

https://doi.org/10.29362/ist20veka.2021.1.ziv.77-98

\title{
SUDBINA NASLEĐA RUSKE EMIGRACIJE U JUGOSLAVIJI 1944-1945.*
}

APSTRAKT: U članku se na osnovu arhivske građe, memoara i literature analizira sudbina nasleđa ruske emigracije u Jugoslaviji (muzeja, biblioteka, arhiva, školskih i zdravstvenih ustanova, kao i grobnih kompleksa) u periodu od 1944. do 1945. godine - po prelasku Crvene armije granica predratne Jugoslavije, oslobodilačkih operacija i dolaska na vlast Komunističke partije Jugoslavije. Ukazuje se na nejednoznačnost odnosa prema nasleđu ruske emigracije i različitu praksu.

KLJUČNE REČI: ruska emigracija, Jugoslavija, nasleđe, muzeji, biblioteke, arhivi, grobni kompleksi

U nekoliko većih talasa, od 1919. do 1924. godine, na teritoriju Kraljevine Srba, Hrvata i Slovenaca (Kraljevinu SHS) pristizale su izbeglice iz Rusije. ${ }^{1}$ Između 41.000 i 44.000 njih nastanilo se u novoj državi, ${ }^{2}$ koja im je pružila srdačan prijem. „Pre svega potrebno je primetiti neobično topao, čak oduševljen odnos Srba prema Rusima bez razlike. Prvim grupama ruskih izbeglica koje su došle iz Odese priređivani su trijumfalni susreti tokom čitavog puta kojim su

\footnotetext{
* Članak je deo projekta Tradicija i transformacija - istorijsko nasleđe i nacionalni identiteti u Srbiji u 20. veku (br. 47019), Instituta za noviju istoriju Srbije, koji finansira Ministarstvo prosvete, nauke i tehnološkog razvoja Republike Srbije.

${ }^{1}$ Руска емиграција у српској култури ХХ века: зборник радова, књ. I-II, уредници Миодраг Сибиновић, Марија Межински и Алексеј Арсењев (Београд: Филолошки факултет, Катедра за славистику и Центар за научни рад, 1994); Мирослав Јовановић, Досељавање руских избеглица у Краљевину СХС 1919-1924 (Београд: Стубови културе, 1996); Мирослав Јовановић, Руска емиграчија на Балкану (1920-1940) (Београд: Чигоја, 2006); Алексеј Тимофејев, Руси и Други светски рат у Југославији: Утииај СССР-а и руских емиграната на догађаје у Југославији 1941-1945 (Београд: Институт за новију историју Србије, 2011); Алексеј Арсењев, Самовари у равници. Руска емиграчија у Војводини (Нови Сад: Змај; Футог: Уметничка радионица Завештање, 2011).

${ }^{2}$ М. Јовановић, Досељавање руских избеглииа..., 186.
} 
išli, sa učešćem najviših predstavnika vojnih i građanskih vlasti i mnoštvom naroda koji je radosno pozdravljao Ruse. ${ }^{\text {(3 }}$ Citirani opis, zabeležen u izveštaju upućenom vladinom opunomoćeniku za smeštaj ruskih izbeglica, Sergeju Nikolajeviču Paleologu, decembra 1920, odslikavao je osobenost odnosa srpskog društva prema izgnanicima. Postojanje specifičnog odnosa prema Rusima potvrdio je i predstavnik Inostranog odeljenja Državne političke uprave (GPU) iz Beča, pribeleživši: „Srbi, prijatelji stare Rusije, za sve su im izlazili u susret, i Rusi, obasipani pažnjom sa svih strana, osećali su se skoro kao kod kuće“. ${ }^{4} \mathrm{U}$ novoj „otadžbini“ sami emigranti su sačuvali svoje običaje i tradicije, nastavili sa svojom delatnošću i to uz pomoć državnih vlasti. Osnivali su sopstvene zajednice, udruženja, medicinske ustanove, biblioteke, muzeje, škole, izgradili su ili uredili hramove u Kraljevini. ${ }^{5}$

Međutim, približavanje jedinica Crvene armije granicama predratne Jugoslavije u jesen 1944. stavilo je Ruse pred ponovni izbor - ostanak u zemlji ili odlazak i novo izbeglištvo. Dozvolu za izbor druge opcije izdejstvovao je od nemačkih okupacionih vlasti komandant Ruskog korpusa, ${ }^{6}$ general Boris Aleksandrovič Štejfon, septembra 1944. godine. Saradnici Biroa za zaštitu interesa ruskih emigranata u Srbiji, jedine emigrantske organizacije u periodu okupacije u Srbiji, ${ }^{7}$ sastavljali su spiskove ljudi koji su želeli da napuste zemlju. ${ }^{8}$ Određen je dan evakuacije, a u centru ruske emigracije - Ruskom domu cara Nikolaja II, ${ }^{9}$ sedištu pomenutog tela, organizovana je registracija Rusa i izdavanje neophodnih dokumenata. Savetovano je da se sa sobom ponese samo najnužnije i

${ }^{3}$ Cit. prema: М. Јовановић, Руска емиграција на Балкану..., 244.

${ }^{4}$ Русская военная эмиграция 20-x - 40-x годов. Документы и материалы, Том II (Москва: Триада-Х, 2001), 112.

5 А. Арсењев, Самовари у равници...; М. Јовановић, Руска емигращија на Балкану..., 288441.

${ }^{6}$ Ruski korpus je predstavljao vojnu formaciju ruskih emigranata koju je septembra 1941. osnovao general Mihail Fjodorovič Skorodumov, kako bi posle likvidacije komunizma u Srbiji bila prebačena na Istočni front s ciljem borbe protiv sovjetske vlasti. Nemci su joj, međutim, namenili drugu aktivnost - antipartizansku delatnost u Srbiji, smenili Skorodumova, a na čelo formacije postavili su Borisa Aleksandroviča Štejfona. U periodu 1941-1945. kroz korpus je prošlo 17.090 vojnika, od kojih je poginulih, teško ranjenih i nestalih bilo 6.709. Detaljnije: Русский Корпус на Балканах во время II Великой войны 1941-1945 г2. Исторический очерк и сборник воспоминания соратников (Нью-Йорк: Наши вести, 1963); Константин Л. Котюков, „Формирование и боевая деятельность Русского охранного корпуса в Югославии в 1941-1945 гг.“, Отечественная история, LII, № 3, (2008), 86-94; А. Тимофејев, Руси и Други светски рат у Југославији..., 41-44, 46-48.

${ }^{7}$ А. Тимофејев, Руси и Други светски рат, 37-41, 43-44.

${ }^{8}$ Исто, 84, 322; Алексей Б. Арсеньев и Михаил Л. Ордовский-Танаевский, Гимназия 6 лииах. Первая русско-сербская гимназия в Белграде (1920-1944), Т. 1 (Белград: Архив Сербской Православной Церкви, 2018), 24.

${ }^{9}$ Остоја Ђурић, Руска литерарна Србија 1920-1941: писии, кружсичи, издања (Горњи Милановац: Дечје новине; Београд: Српски фонд словенске писмености и словенских култуpa, 1990), 40-41; Остоја Ђурић, „Шездесет година Руског дома Императора Николаја II у Београду (1933-1993)“, у: Руска емиграчија у српској култури ХХ века: зборник радова, књ. I, 123-128; Милан Просен, „75 година Руског дома у Београду“, Наслеђе, IX, бр. 9, (2008), 211-220. 
najvrednije i to u ograničenim količinama - koliko je ko mogao da nosi. Do stanice Zemun, gde je bio pripremljen voz, emigrante, podeljene na grupe, prevozili su kamioni. ,Završivši ukrcavanje prve grupe, automobili su krenuli na put. Formiravši kolonu, kretali su se po pustim ulicama prema novom mostu preko Save. Bilo je rano i grad je još uvek spavao. Sporo smo se kretali, prešli most i povećavajući brzinu, počeli smo brzo da se udaljavamo od Beograda. U jutarnjoj magli iščezavala je strma obala Save, prekrivena zgradama, Kalemegdan, Patrijaršijski dom, Saborna crkva i samo je krst na zvonari, kao da blagoslovljava one koji odlaze, ostao vidljiv na nebu. Svako je bio zauzet svojim mislima. Neki su prekrivši lice maramom, pokušali da sakriju suze koje su nadolazile, drugi su se krstili i šaputali molitve... Tragedija se ponovila - kao što su pre dvadeset i četiri godine, takođe u jesen, ruski ljudi napuštali svoju Otadžbinu, tako su se i sada rastajali sa usnulom rodnom zemljom i njenim narodom (...) Zbogom, naš grade, možda i zauvek." ${ }^{\text {10 }}$

Prema procenama stručnjaka za istoriju ruske emigracije Alekseja Arsenjeva, oko 60\% ruskih Beograđana je napustilo prestonicu, a većina emigrantskih porodica Novi Sad. ${ }^{11}$ Odlazeći u novo izbeglištvo ponovo su poneli sa sobom najvrednije stvari, među kojima su bile ikone i barjaci. Čudotvornu ikonu Presvete Bogorodice „Kurskaja-Znamenija“ poglavar Ruske pravoslavne zagranične crkve mitropolit Anastasije (Gribanovski) poneo je napuštajući zemlju, ${ }^{12}$ a septembra 1944. iznete su ruske zastave koje su se nalazile u ruskom hramu Svete Trojice ${ }^{13}$ u Beogradu. ${ }^{14}$ Naime, na molbu generala Vladimira Vladimiroviča Krejtera, rukovodioca Biroa za zaštitu interesa ruskih izbeglica, gauptšturmfirer SS M. G. Grinev iz posebnog puka SS „Varjag“ preuzeo je zastave, koje su prethodno bile spakovane u četiri kutije. Po dolasku u Drezden, Grinev ih je predao lideru Ruskog nacionalnog i socijalnog pokreta pukovniku N. D. Skalonu. Iz bombardovanog hrama u Drezdenu, zastave su bile prenete u gradsku banku, odakle su ih preuzele sovjetske jedinice i odnele u SSSR. ${ }^{15}$

Od oko 30.000 emigranata koji su živeli u Kraljevini Jugoslaviji 1941. godine, ${ }^{16}$ odnosno 21.650 tokom 1942. na teritoriji Srbije pod nemačkom oku-

10 В. С. Данилов, „Эвакуация русской белой эмиграции из Югославии“, Кадетская перекличка, XI, № 28, (1981), 88-89.

11 Алексей Б. Арсеньев, У излучины Дуная: Очерки жизни и деятельности русских в Новом Саду (Москва: Русский путь, 1995); А. Арсеньев и М. Ордовский-Танаевский, op. cit., Т. 1, 24.

12 Владислав А. Маевский, Русские в Югославии: Взаимоотношения России и Сербии, Т. 2 (Нью-Йорк: Ист. кружок, 1966), 354.

13 O ruskoj crkvi u Beogradu detaljnije: В. Маевский, op. cit., 23-29; Виктор И. Косик, „Русская церковь в Югославии 1921-1939 годы“, Славяноведение, XXXII, № 6, (1996), 69; М. Јовановић, Руска емиграиија..., 344-346.

$14 \mathrm{O}$ ruskim zastavama u ruskom hramu detaljnije: Тимофей Н. Шевяков и Олег Пархаев, Знамена и штандарты Российской императорской армии конща XIX - начала XX 6. (Москва: АСТ, Астрель, 2002); Константин К. Семенов, „Святыни Русской армии в храме Святой Троицы в Белграде (1924-1944 гг.) г.“, Ежегодник Дома русского зарубежья имени Александра Солженицына, VII, № 7, (2017), 89-113.

${ }^{15}$ К. Семенов, „Святыни Русской армии...“, 112.

${ }^{16}$ А. Тимофејев, Руси и Други светски рат у Југославији ..., 25. 
pacijom (ne uključujući one koji su imali jugoslovensko državljanstvo), ${ }^{17} \mathrm{u}$ državi je novembra 1945, prema sovjetskim podacima, ostalo 12.519 (s tim da su u pomenutu brojku bili uključeni Rusi koji nisu imali državljanstvo Jugoslavije ili neke druge države). ${ }^{18}$ Prema, pak, preciznijim podacima Ministarstva unutrašnjih poslova FNRJ, sredinom 1949. broj Rusa u državi je iznosio 13.057 - sovjetsko državljanstvo je imalo 5.874, a jugoslovensko 6.887. ${ }^{19}$ Motivi za ostanak bili su razni. Njih je moguće predstaviti sledećim odlomcima: „Matrona Nazarovna, žena Porfirija Kondratoviča Verbickog, sašila je crvenu zastavu sa srpom i čekićem, čekajući Ruse u Beloj Crkvi. - Eh, mama, - govorio joj je muž, - ti si od njih pobegla, onda... Ti ćeš njima zastavu, a oni će tebe na banderu. - Ja volim svoj narod, - odgovorila je. - I neka mi čine šta hoće“. ${ }^{20}$ „Znatan broj tih žitelja (ruskih žitelja - M. Ž.) očekivao je dolazak sovjetske vojske spokojno, uveren u to da se 'za dvadeset i pet godina mnogo promenilo i da boljševici više nisu to što su nekada bili. ${ }^{\text {'،21 }}$ Rusi koji su se opredelili za ostanak u zemlji spalili su dokumente iz ličnih arhiva, fotografije u uniformama, sakrili ordenje i relikvije iz carskog vremena. ${ }^{22}$

Okončanje vojnih operacija u zemlji označilo je početak akcija protiv ruskih emigranata. Nove vlasti i organi Narodnog komesarijata za unutrašnje poslove (NKVD) počeli su sa saslušavanjima pojedinih članova ruskih zajednica, nakon čega su usledila hapšenja i smeštanja u logor. Izvestan broj je bio streljan (u Beloj Crkvi izvan grada i u Zagrebu), jedan deo deportovan, pojedini su pušteni, a zabeleženi su i slučajevi samoubistva. ${ }^{23}$ Objavljena je bila i obavezna registracija svih Rusa u Beogradu. Svi prijavljeni su, međutim, zadržani u pritvoru, a na intervenciju Saveza sovjetskih patriota, ${ }^{24}$ antifašističke organiza-

${ }^{17}$ А. Арсеньев и М. Ордовский-Танаевский, оp. cit., Т. 1, 22.

18 Алексеј Тимофејев, прир., Црвена армија и руска емиграиија у Југославији за време Другог светског рата у огледалу анти ИБ-овске пропаганде (Београд: Центар за изучавање Традиције Укронија, 2018); Алексей Ю. Тимофеев, „Сломанные судьбы. 1948-1953 гг. Репрессии первого послевоенного десятилетия против русской эмиграции в Югославии (по материалам Управления Государственной безопасности)“, Ежегодник Дома русского зарубежья им. Александра Солженищьнна, IX, № 9, (2019), 295.

19 А. Арсеньев и М. Ордовский-Танаевский, op. cit., Т. 1, 25.

${ }^{20}$ Cit. prema: А. Арсењев, Самовари у равници...

${ }^{21}$ В. Курганский, „Тридцать лет тому назад“, Кадетская перекличка, IV, № 11, (1975), 58.

${ }^{22}$ Tatjana Puškadija-Ribkin, Emigranti iz Rusije u kulturnom i znanstvenom životu Zagreba (Zagreb: Prosvjeta, 2006), 189-249; Алексеј Арсењев, „Руси у Банату“, у: Банат кроз векове. Слојеви култура Баната: Зборник радова, уредник Миодраг Матицки (Београд: Вукова задужбина, 2010), 663-712.

23 А. Арсењев, „Руси у Банату“, у: Банат кроз векове. Слојеви култура Баната: Зборник радова, 663-712.

24 O Savezu sovjetskih patriota: Алексеј Тимофејев, „Савез совјетских патриота антифашистичка организација руских емиграната у Србији 1941-1945“, Токови историје, XX, бр. 3, (2012), 257-277; Наталия А. Ёхина, „, 'История русского Сопротивления... еще не написана' К истории Союза советских патриотов в Югославии в годы Второй мировой войны“, Ежегодник Дома русского зарубежья имени Александра Солженицына, IV, № 4-5, (2014-2015), 174-205; Наталия А. Ёхина, ,'На чьей стороне ты будешь, когда разразится война': К истории Союза советских патриотов в Белграде“, в: Российская эмиграция в борьбе с фашизмом. Международная научная конференция, составитель 
cije ruskih emigranata koja je formirana tokom rata i pomagala Crvenoj armiji i Narodnooslobodilačkoj vojsci Jugoslavije, ${ }^{25}$ većina pritvorenih je ubrzo oslobođena. Istovremeno, prvih meseci posle rata u javnosti su preovladavali osuđujući tonovi u pogledu delatnosti ove zajednice. ${ }^{26}$ Štampa je navodila da su predstavnici ove grupacije opisivani kao oružje upereno protiv ruskog naroda, ${ }^{27}$ „,izdajničke bande“ ${ }^{28}$ koji su ,vodili lažnu i klevetničku kampanju protiv svoje domovine i takav stav krunisali izdajstvom naše zemlje i služenjem nemačkim fašistima, smrtnim neprijateljima svih Slovena“. ${ }^{29}$

Odnos prema Rusima tokom prvih godina, međutim, nije bio jednostran. Nakon 1945. oni su integrisani u jugoslovensko društvo, a u periodu 19461948. tri bivša izgnanika - hemičar Nikolaj Antonovič Pušin, inženjer Vladimir Vladimirovič Farmakovski i vizantolog Georgij Aleksandrovič Ostrogorski postala su članovi Srpske kraljevske akademije / Srpske akademije nauka. ${ }^{30}$ Upravo takva nejednoznačnost bila je vidljiva i na primeru odnosa novih vlasti, ali i jedinica Crvene armije, prema nasleđu ruske emigracije.

Među onima koji su u jesen 1944. krenuli u novo izbeglištvo bili su i učenici tri ruske obrazovne ustanove koje su radile i tokom okupacije - Prvog ruskog velikog kneza Konstantina Konstantinoviča kadetskog korpusa iz Bele Crkve (srednjeg vojnog učilišta), ${ }^{31}$ i muške i ženske gimnazije u Beogradu

Константин К. Семенов (Москва: Дом русского зарубежья им. Александра Солженицына, 2015), 203-237.

25 А. Тимофејев, „Савез совјетских патриота...“, 270.

${ }^{26}$ Uporediti sa kulturom sećanja na ulogu Crvene armije u oslobodilačkim operacijama: Милана Живановић, „Политика сећања у Југославији на ослободилачке операције 1944. и улогу Црвене армије“, Токови историје, XXVIII, бр. 2, (2020),139-160.

27 „Фјодор Јевдокимович Махин генерал-лајтнант“, Борба, 4. 6. 1945, 1.

28 „Свечана сахрана генерал-лајтнанта Фјодора Махина“, Политика, 6. 6. 1945, 5.

29 „Сахрана генерал-лајтнанта Фјодора Јевдокимовича Махина“, Борба, 5. 6. 1945, 1.

${ }^{30}$ Njih osam su do 1941. bili udostojeni tim prestižnim priznanjem. Марина Ю. Сорокина, „Пересекая границы: российские ученые-эмигранты - члены Сербской академии науки и искусств“, в: Русская диаспора и изучение русского языка и русской культуры в инославянском и иностранном окружении, редактор Боголюб Станкович (Белград: Славистичко друштво Србије, 2012), 72, 76-77.

${ }^{31}$ Po dolasku u Sarajevo 1920. godine 263 kadeta i 40 članova personala, nastavnika i vaspitača Ruskog kadetskog korpusa smešteni su u kasarnu u centru grada. Septembra 1929. korpus je preseljen u kasarne u Beloj Crkvi, u kojima je od 1922. boravio Krimski kadetski korpus. Sa njim se spojio i promenio naziv u Prvi ruski velikog kneza Konstantina Konstantinoviča kadetski korpus. O Ruskom kadetskom korpusu i ostalim obrazovnim ustanovama u Kraljevini SHS/Jugoslaviji: Русский кадетский корпус. Кадетская памятка 1920-1925. Второй сборник Константиновскаго кружка (Сараево: Русский кадетский корпус, 1925); Кадетские корпуса за рубежом: 1920-1945 (Нью-Йорк: Объединение кадет российских зарубежных кадетских корпусов, 1970), 177-320; Љубодраг Димић, „Руско школство у Краљевини Југославији 1918-1941“, у: Руска емиграција у српској култури ХХ века: зборник радова, Т. 2, уредници Миодраг Сибиновић, Марија Межински и Алексеј Арсењев (Београд: Филолошки факултет, Катедра за славистику и Центар за научни рад, 1994); Тома Миленковић, Школовағе деце емиграната из Русије у Југославији 19191941 (Београд: Завод за уџбенике, 2004); Владлен А. Гурковский, Российские кадетские корпуса за рубежом (Москва: Белый Берег, 2009), 107-153; А. Арсењев, Самовари у равници...; А. Арсеньев и М. Ордовский-Танаевский, op. cit. 
(osnovane 1920. kao Prva rusko-srpska gimnazija, a 1930. razdvojene na mušku i žensku). Oko 190 kadeta korpusa je na čelu sa direktorom ove školske ustanove Aleksandrom Grigorjevičem Popovim 10. septembra napustilo ovaj banatski grad, a dva dana kasnije evakuisani su i gimnazijalci iz Beograda. ${ }^{32}$ Time je okončano postojanje tih škola.

No, ne samo njih, već i muzeja Ruskog kadetskog korpusa, osnovanog 1925. u Sarajevu, u kojem je do 1929. bila smeštena ova obrazovna ustanova, s ciljem sakupljanja „,svih materijalnih dokaza života“"33 nekolicine ruskih kadetskih korpusa. Do 1940. Muzej je formirao bogatu kolekciju koja je brojala nekoliko hiljada eksponata, među kojima je bilo veoma vrednih predmeta vezanih za istoriju carske Rusije i Belog pokreta. ${ }^{34}$ Pred evakuaciju kadeta ovog korpusa septembra 1944, prema naredbi njegovog direktora, sa držača je sklonjena zastava Polockog korpusa, ruska relikvija, ${ }^{35}$ i predata rukovodiocu, koji je odneo u Nemačku. ${ }^{36}$ Muzejski eksponati, međutim, nisu bili evakuisani. Po dolasku Crvene armije u grad oktobra 1944, ruske trofejne i vojne zastave koje su sačinjavale deo fundusa Muzeja, čuvar ove ustanove, pukovnik Petar Vladimirovič Barišev predao je sovjetskoj strani. One su otpremljene u Moskvu i predate na čuvanje tadašnjem Vojno-istorijskom muzeju. ${ }^{37}$ Ostali, pak, predmeti iz raskošne muzejske kolekcije su po nalogu načelnika sovjetske armije izneti van zgrade u kojoj je bio smešten korpus, stavljeni na gomilu i spaljeni. ${ }^{38}$ Ipak, sačuvana je još jedna relikvija - zastava Simbirskog korpusa. ${ }^{39}$ Zastava je ostala u Jugoslaviji sve do 1951. kada ju je u Trst odneo ruski sveštenik, da bi potom bila preneta u SAD i predata Udruženju kadeta u San Francisku. ${ }^{40}$

Izvesne mere su bile preduzete i u slučaju drugih muzejskih kolekcija, na primer Muzeja ruske konjice, ${ }^{41}$ i Muzeja sećanja na imperatora Nikolaja II. Muzej ruske konjice je osnovan u Beogradu 1930. s ciljem prikupljanja materijala vezanih za istoriju konjičkih pukova i baterija ruske armije. Do 1936. sakupljeno je

32 А. Арсењев, Самовари у равниции..; А. Арсеньев и М. Ордовский-Танаевский, op. cit., Т. $1,51,78-79$.

33 Опись музея с отделами: генерал Врангель, Русский военный, российские кадетские корпуса и военныя училища, зарубежныя военно-учебныя организачи (Белая Церковь: Великого Князя Константина Константиновича кадетский корпус, 1933), 3.

34 Detaljnije: Седьмая кадетская памятка. Юбилейная. 1920-1995 (Нью-Йорк: Издательство Объединения кадет Российских кадетских корпусов, 1997); Опись музея..., 3-208.

${ }^{35}$ Описъ музея..., 116-117, 162.

${ }^{36}$ Godine 1949. zastava je iz Nemačke odneta u SAD. Čuvala se u Sinodalnoj sabornoj crkvi Znamenja Majke Božije. Седьмая кадетская памятка. Юбилейная. 1920-1995 (Нью-Йорк: Издательство Объединения кадет Российских кадетских корпусов, 1997).

${ }^{37}$ Ikone, pak, priručne crkve Ruskog kadetskog korpusa u Beloj Crkvi bile su odnete u ruski hram Sv. Jovana Bogoslova u tom gradu. А. Арсењев, „Руси у Банату“, 663-712.

${ }^{38}$ Г. А. Кованько, „Ужин в Москве“, Кадетская перекличка, ХХI, № 48, (1990), 62-63.

${ }^{39}$ Описъ музея..., 168; Русский кадетский корпус. Кадетская памятка 1920-1925.., 19.

40 Седьмая кадетская памятка. Юбилейная. 1920-1995 (Нью-Йорк: Издательство Объединения кадет Российских кадетских корпусов, 1997).

41 Музей-архив русской культуры в Сан-Франциско, Коллекции переписки Петра Филаретовича Константинова, Письмо Петра Филаретовича Константинова к Виталию Петровичу Дробашевскому. Autorka se zahvaljuje Ivu Frankenu na ovom dokumentu. 
preko 500 fotografija, slika i litografija. Od kraja tridesetih godina bio je smešten u zgradi Ruskog doma. ${ }^{42} \mathrm{U}$ istoj zgradi nalazio se i Muzej sećanja na imperatora Nikolaja II. Pitanje njegovog osnivanja pokrenulo je Društvo za uspomenu na cara Nikolaja II ubrzo nakon sopstvenog konstituisanja 1928. sa idejom organizacije muzeja-čuvara relikvija i predmeta vezanih za sećanje na imperatora Nikolaja II. Muzej je svečano otvoren u Ruskom domu u Beogradu 1936. godine. ${ }^{43}$

Za vreme okupacije Srbije, od pomenutih muzeja ali i Opšteg muzeja u zgradi nekadašnjeg ruskog carskog poslanstva u Ulici kralja Milana formiran je Ruski ujedinjeni muzej. Ubrzo po poslednjem savezničkom bombardovanju Beograda septembra 1944. na molbu Uprave ruske emigracije u Srbiji Ministarstvo prosvete i vera je uzelo pod zaštitu Ruski muzej, donevši odluku da se predmeti predaju na čuvanje u Muzej kneza Pavla, a delimično u Vojni muzej. Izvesno je da je jedan deo predmeta iz Ruskog muzeja prenet u Vojni muzej. ${ }^{44}$ Među njima su se nalazili i eksponati iz zbirke Muzeja ruske konjice. ${ }^{45}$ Naime, prema navodima člana njegove muzejske komisije, Vitalija Petroviča Drobaševskog, predmeti tog muzeja i Muzeja sećanja na imperatora Nikolaja II bili su spakovani u kutije i predati u posebno sklonište radi zaštite od bombi. Sami, pak, eksponati Muzeja ruske konjice su bili ustupljeni jednom muzeju u zemlji, u kojem su bili sačuvani. Drobaševski je takođe navodio da su 1944. godine eksponati Muzeja sećanja na imperatora Nikolaja II bili predati na čuvanje drugom muzeju u Jugoslaviji. ${ }^{46}$ Međutim, po završetku Drugog svetskog rata, jedan deo eksponata iz tog muzeja je otpremljen u SSSR. U Državni istorijski muzej u Moskvi je 1947. preko Komiteta za kulturno-prosvetne ustanove pri Savetu ministara od ženske delegacije SSSR, koja je posetila Beograd po liniji Antifašističkog komiteta SSSR-a, upućen deo predmeta iz kolekcije Muzeja. ${ }^{47}$

Znamenja Kubanske kozačke vojske, koja su juna 1941. iz Vojnog muzeja preneta u Kubanski štab u Beogradu i Ruski dom, po odluci atamana Kubanske kozačke vojske u emigraciji V. G. Naumenka vozom su septembra 1944. otpremljena u Nemačku. ${ }^{48}$

42 O Muzeju ruske konjice u Beogradu detaljnije: Виталий П. Дробашевский, „Справка о Музее русской конницы в г. Белграде“, в: Хранилища памятников культуры и истории Зарубежной Руси (Сан-Франциско: Музей Русской Культуры в Сан-Франциско, 1966), 97-98; Елена И. Соколова, „Музей русской конницы в Белграде“, Военно-исторический журнал, XLVI, № 11, (2001), 41.

${ }^{43}$ Музеј за успомену на Цара Николу II: Каталог (Београд: Друштво за успомену на Цара Николу II, 1936), 3.

44 Предраг Лажетић, Војни музеј: 1878-2014 (Београд: Медија центар „Одбрана“, 2014), $152-153$.

45 Музей-архив русской культуры в Сан-Франциско, Коллекции переписки Петра Филаретовича Константинова, Письмо Петра Филаретовича Константинова к Виталию Петровичу Дробашевскому.

${ }^{46}$ В. Дробашевский, „Справка о Музее русской...“, 97-98.

47 М. В. Фалалеева, „Фонд Романовых в собрании ОПИ ГМИ“, в: Археографический ежегодник за 1996 г., редактор Сигурд О. Шмидт (Москва: Наука, 1998), 278.

48 Султан Н. Якаев, Одиссея казачьих регалий: [Кубан. казачество за рубежсм] (Краснодар: Б. и., 1992); Наталья А. Корсакова, „Дневники атамана Кубанского казачества в Зарубежье В. Г. Науменко как источник о судьбе кубанских войсковых 
I u slučaju ruskih biblioteka zabeležene su antagonističke pojave. ${ }^{49}$ Privatna biblioteka pukovnika Stepana Fjodoroviča Klimentova u Petrovgradu (današnjem Zrenjaninu) bila je razgrabljena od strane vojnika i oficira Crvene armije, a novembra 1944. naredbom privremene sovjetske vojne oblasne uprave spaljena je skoro sva ruska emigrantska periodika i znatan deo knjiga iz biblioteke novosadskog odeljenja kulturne organizacije Ruska matica. ${ }^{50}$ Deo knjižnog fonda - nekoliko hiljada naslova, poklonjen je Biblioteci Matice srpske, a manji broj beletrističkih dela predat je Narodnoj biblioteci „Đuro Daničič““ ${ }^{51}$ Veći deo knjižnog fonda biblioteke Ruske matice iz Ljubljane (iako je od oko 10.000 naslova pronađeno 6.500), koji su 1945. jugoslovenske vlasti konfiskovale, bio je predat Društvu za kulturnu saradnju sa SSSR-om. ${ }^{52}$ I ostaci biblioteke štaba glavnokomandujućeg Dobrovoljačke armije, generala Petra Nikolajeviča Vrangela i biblioteke ruske kolonije u Sremskim Karlovcima sačuvani su u kućici ruske porodice Sokolov u ovoj varoši, ${ }^{53}$ dok su pojedine gradske biblioteke

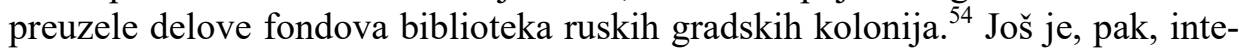
resantnija sudbina Ruske javne biblioteke, koja se nalazila u zgradi Ruskog doma, a čiji je knjižni fond u leto 1944 . brojao oko 130.000 naslova. ${ }^{55}$ Po oslobođenju Beograda ona je, prema navodima nekadašnjeg bibliotekara Patrijaršijske biblioteke, Vladislava Aljbinoviča Majevskog, nastavila da izdaje knjige čitaocima. U januaru 1945, međutim, sovjetska strana je postavila pitanje predaje zgrade bivšeg ruskog carskog poslanstva i dva zdanja (među kojima je bio i

регалий“, в: Зарубежсная Россия. 1917-1939 г2.: Сборник статей (Санкт-Петербург: Лики России, 2000), 86-90; Пути-дороги кубанских войсковых регалий на чужбине, Из дневников атамана В. Г. Науменко с комментариями Н. В. Назаренко (Краснодар: КГУКИ, 2000); Љубица Дабић, „Руско одељење у Војном музеју у Београду 1936-1941. г.“, Зборник Историјског музеја Србије, XXXI, бр. 31, (2003), 331-332.

49 Treba istaći interesantan dopis koji je Povereništvo za građevine NKOJ-a uputilo februara 1945. Povereništvu za prosvetu ASNOS-a, u kojem se isticalo da su u Umetnički muzej (nekadašnji Muzej kneza Pavla) prenete biblioteke narodnih neprijatelja, koje je specijalna komisija razvrstala po grupama. Imajući u vidu činjenicu da su se knjige delile pojedinim ustanovama, Povereništvo za građevine je tražilo od Povereništva za prosvetu ASNOS-a odobrenje da za svoju biblioteku odabere knjige koje se odnose na inženjersku struku. Arhiv Jugoslavije (AJ), fond 13, Ministarstvo građevina Vlade FNRJ, fascikla 3, Povereništvo za građevine NKOJ Povereništvu za prosvetu ASNOS, 10. februar 1945.

${ }^{50}$ Ova organizacija je osnovana 1924. s ciljem očuvanja odnosno razvoja nacionalnog identiteta, učvršćivanja veza između ruskih izbeglica i vođenja kulturne delatnosti. Александр Д. Билимович, Русская матица (Любляна: Русской матицы, 1924); Русская матица (19241934): Отчет о деятельности (Любляна: Русская матица, 1935).

${ }^{51}$ А. Б. Арсеньев, У излучины Дуная...

52 Аля Брглез, „Организация русских эмигрантов в Словении“, Россия и современный мир, XXIV, № 4, (2016), 198, 200.

${ }^{53}$ А. Арсењев, Самовари у равници...

54 Драгиња Рамадански, „Библиотека колоније руских избеглица у Сенти“, у: Руска емиграција у српској култури ХХ века: зборник радова, књ. II, 42-48; Несиба ПалибркСукич, „Библиотека русской колонии в Городской библиотеке города Панчево“, в: Русская диаспора и изучение русского языка и русской культуры в инославянском и иностранном окружении, 239.

55 А. Тимофејев, Руси и Други светски рат у Југославији..., 85. 
Ruski dom), zajedno sa njihovim bibliotekama, na parceli između ulica kralja Milana i kraljice Natalije u Beogradu. ${ }^{56}$ Uskoro je bilo i zabranjeno izdavanje knjiga. Nekadašnji saradnik biblioteke je pisao da „vrata nisu zatvarana; samo je na ulazu stajao jugoslovenski partizan sa puškom, koji nije propuštao civile“ ${ }^{57}$ No, znatan broj knjiga je bio sačuvan.$^{58}$ Naime, 1947. direktor Doma je nezvanično otvorio biblioteku koju je formirao, između ostalih, i od izabranih knjiga iz fonda biblioteke Ruskog doma. Prema sopstvenim navodima, ,pod velikim slojem prašine i prljavštine" zatekao je 60.000-70.000 knjiga, poslavši pritom u SSSR jedan vagon onih za koje je smatrao da poseduju arhivističku i kulturnu vrednost, pripremajući potom još jedan. Kao korisne za potrebe biblioteke procenio je 15.000-20.000 naslova, s tim da je, treba istaći, izvestan broj knjiga bio i spaljen. ${ }^{59}$ Nekoliko hiljada naslova je zatim poklonjeno Društvu za saradnju sa SSSR-om, a nakon njegovog ukidanja 1949. predato Biblioteci grada Beograda, u kojoj su poznih šezdesetih rashodovani kao papirni otpad. ${ }^{60}$

Osim ruskih zastava i predmeta, iz Jugoslavije su odneti i arhivi pojedinih emigrantskih ustanova. U Moskvu su iz prostorija Patrijaršijskog dvora u Sremskim Karlovcima 1945. sovjetski organi poslali arhivu Kancelarije Arhijerejskog sinoda Ruske pravoslavne zagranične crkve, dominantne duhovne strukture u izbeglištvu, čiji je centar bio upravo u pomenutoj varoši. ${ }^{61}$ Sama arhiva je čuvana u Centralnom državnom Posebnom arhivu SSSR. ${ }^{62}$ Sovjetski obaveštajci

${ }^{56}$ Российский государственный архив социально-политической истории, фонд 82 , Молотов Вячеслав Михайлович, опись 2, дело 1373, лист 75.

${ }^{57}$ Cit. prema: В. Маевский, op. cit., 54.

${ }^{58}$ Владимир П. Гудков, „Четыре десятилетия общения и дружбы. Югославянская история в новое и новейшее время“", в: Материалы научных чтений, посвященных 80-летию со дня рождения проф. В. Г. Карасева (1922-1991) (Москва: Издательство Московского университета, 2002), 258; Алексей Б. Арсеньев, „Люди и книги: семья Малининых и их библиотека“, Русское зарубежье и славянский мир. Сборник трудов, составитель Петр Буняк (Белград: Славистическое общество Сербии, 2013), 221.

${ }^{59} \mathrm{U}$ fondu je sačuvano između 8.000 i 10.000 naslova iz strane literature. Марко Пејовић, „Односи Друштва за културну сарадњу Југославија-СССР и Свесавезног друштва за културне везе са иностранством 1945-1948“ (магистарски рад, Универзитет у Београду, Филозофски факултет, Одељење за историју, 2010), 36.

60 Јован Качаки, Руске избеглице у Краљевини СХС/Југославији. Библиографија радова 1920-1944: покушај реконструкиије (Београд: Књижара Жагор; Универзитетска библиотека, 2003), 50.

${ }^{61}$ O Ruskoj zagraničnoj crkvi: Miroslav Jovanović, „Sveštenik i društvo: eto parole“ - Ruska pravoslavna zagranična crkva na Balkanu 1920-1940“, Tokovi istorije, XIII, br. 3-4, (2005), 67-100; М. Јовановић, Руска емиграчија на Балкану..., 316-325; Мирослав Јовановић, „Руска православна загранична црква у Југославији током двадесетих и тридесетих година 20. века“", Српска теологија у двадесетом веку - истраживачки проблеми и резултати: зборник радова научног скупа 3, приредио Богољуб Шијаковић (Београд: Православни богословски факултет, 2008), 160-178; Владислав Пузовић, „Руска загранична црква у периоду између два светска рата: преглед литературе у Србији“, Српска теологија данас 2009 - зборник радова првог годишьег симпосиона одржаног на Православном богословском факултету 29-30. маја 2009, приредио Богољуб Шијаковић (Београд: Православни богословски факултет-Институт за теолошка истраживања, 2010), 386-391; А. Тимофејев, Руси и Други светски рат у Југославији ..., 92-106.

62 А. Арсењев, Самовари у равници... 
su u Moskvu otpremili i arhive dve ruske gimnazije u Beogradu, sva tri kadetska korpusa i sva tri devojačka instituta, kao i ruskih organizacija - Sveruskog saveza gradova i Sveruskog zemskog saveza. ${ }^{63}$ Iz zgrade Ruskog doma u SSSR je otpremljen i arhiv Saveza pobornika čistote ruskog jezika. ${ }^{64}$

Sam, pak, centar ruske emigracije, simbol ruske kulture - Ruski dom cara Nikolaja II, doživeo je transformaciju postavši obeležje sovjetske ideologije. Ova zgrada je bila predata Sovjetskom Savezu, budući da je katastarska parcela na kojoj je bio izgrađen pripadala Ruskoj državi, ${ }^{65}$ čiji je pravni naslednik bio SSSR. Ovaj centar delatnosti Rusa ne samo u prestonici, već u celoj Jugoslaviji, bio je izgrađen s ciljem negovanja i očuvanja nacionalne kulture. Svečano otvoren 1933, predstavljao je stecište nekolicine značajnih ruskih ustanova - Ruske javne biblioteke, muške i ženske gimnazije, Državne komisije za ruske izbeglice, Muzeja ruske konjice i Muzeja sećanja na imperatora Nikolaja II, Ruskog slikarskog društva, Ruskog muzičkog društva, Ruskog naučnog instituta. ${ }^{66}$ Tokom okupacije predstavljao je sedište Biroa za zaštitu interesa ruskih izbeglica.

Po oslobođenju Beograda, u zgradu se smestio Savez sovjetskih patriota. Budući da je tokom borbi za oslobođenje glavnog grada Dom delimično izgoreo, njegovi članovi su uređivali prostorije zgrade, ali i slikali portrete sovjetskih lidera. ${ }^{67}$ Međutim, kao što je navedeno, već januara 1945. sovjetska strana je istakla zahtev za predaju zgrade bivšeg ruskog carskog poslanstva $\mathrm{i}$ Ruskog doma, pridajući mu političku dimenziju. No, usled oštećenja zgrade, usledila je njena rekonstrukcija koju su sproveli jugoslovenski organi. Po završetku remonta, decembra 1945. Dom je predat sovjetskoj ambasadi u Beogradu. Nekoliko meseci kasnije, promenjena je i njegova namena. Juna 1946. Savet ministara SSSR je doneo odluku o osnivanju Doma sovjetske kulture. ${ }^{68}$ Međutim, uprkos promeni imena, u javnosti se održao stariji naziv. U beogradskim listovima je nastavljeno sa upotrebom termina „Ruski dom“ ili je lokacija Doma sovjetske kulture bila praćena razjašnjenjima da se radi o „Ruskom domu“ odnosno „bivšem Ruskom domu“. Ovaj naziv je korišćen čak i u izveštaju Društva za kulturnu saradnju Jugoslavije sa SSSR-om 1947. godine. $^{69}$

Osim uticaja na ustanove kulture, oslobodilačke operacije u zemlji ili njihov završetak imali su posledice i po rad pojedinih ruskih medicinskih ustanova poput bolnice-sanatorijuma u Pančevu. Neposredan povod za organizova-

\footnotetext{
${ }^{63}$ Момчило Павловић и Тома Миленковић, прир., Белоемиграција у Југославији 1918-1941, Том I (Београд: Институт за савремену историју, 2006), 19.

64 Алексей Арсеньев, „Культурные организации русской интеллигенции в Югославии 1920-1940 гг.“, в: Блоковский сборник (Тарту: Tartu Ülikooli Kirjastus, 1996), 335.

${ }^{65}$ Istorijski arhiv Beograda, fond 6, Opština grada Beograda, 27-33-1931.

${ }^{66}$ О. Ђурић, „Шездесет година Руског дома...“”, 124.

${ }^{67}$ А. Тимофејев, „Савез совјетских патриота...“, 270.

${ }^{68}$ М. Пејовић, „Односи Друштва за културну сарадњу...“, 35.

69 Милана Живанович, „Молот в руках красных: судьба Русского дома после 1944 г.“, Ежегодник Дома русского зарубежья имени Александра Солженииына, IX, № 9, (2019), $358-360$.
} 
nje Ruske bolnice-sanatorijuma Ruskog društva Crvenog krsta (stare organizacije) marta 1920. u ovom banatskom gradu bio je dolazak velikog broja lekara, ali i izbeglica zaraženih tifusom kojima je bilo neophodno pružiti ne samo medicinsku, već i sanitarnu pomoć. Iako nastala kao forma borbe protiv tifusa, ova ustanova će vremenom prerasti u bolnicu sa 110 postelja, tri operacione sale, previjalištem, porodilištem, laboratorijom, kabinetima za rentgenoskopiju i fizioterapiju. ${ }^{70}$ Svoju delatnost je obavljala do oktobra 1944. kada je pretvorena u Bolnicu za lake ranjenike, kojom je do leta 1945. rukovodila dr Jelizaveta Berkovič, major medicinske službe Crvene armije. Ova medicinska ustanova je zatvorena krajem januara 1946. godine. ${ }^{71}$

Svoj rad po završetku vojnih operacija nastavila je i Ruska poliklinika u Beogradu. Ova ustanova je otvorena aprila 1920. kao Ambulanta Ruskog društva Crvenog krsta (stare organizacije) s ciljem pružanja pomoći pristiglim ruskim izbeglicama, da bi 1937. odlukom Ministarstva socijalne politike i narodnog zdravlja usled porasta obima i raznovrsnosti rada prerasla u Polikliniku Ruskog crvenog krsta. ${ }^{72}$ Sa prijemom pacijenata nastavila je i u periodu okupacije, a tokom borbi za oslobođenje Beograda od oktobra 1944. obavljala je funkciju ,prihvatne stanice“ za ranjene vojnike Crvene armije, partizane i građane. Okončanjem okupacije svakodnevno je primala pacijente, a oktobra 1945. u njoj je radilo 19 lekara. Ukinuta je 1946. godine. ${ }^{73}$ Do pedesetih godina, međutim, rad je nastavilo Sklonište Ruskog društva Crvenog krsta (stare organizacije) za prestarele, invalide i nesposobne u Velikoj Kikindi. Radilo se o ustanovi socijalnog staranja - staračkom domu, koji je bio osnovan u Igalu 1920, ali je usled finansijskih poteškoća premešten 11 godina kasnije u ovaj grad u Vojvodini. Svoju delatnost je obavljao tokom rata, ali i po njegovom završetku, potpadajući pod nadležnost Povereništva za socijalno staranje Glavnog narodnog odbora Autonomne pokrajine Vojvodine. ${ }^{74}$

Približavanje Crvene armije granicama predratne Jugoslavije koje je uslovilo evakuaciju sveštenstva i Svetog arhijerejskog Sinoda Ruske pravoslavne zagranične crkve na čelu sa mitropolitom Anastasijem (Gribanovskim), kao i uspostavljanje nove vlasti, odrazilo se i na duhovne strukture ruske emigracije koje su ostale u zemlji. Pre nego što će napustiti zemlju, doneli su akt kojim je uprava nad ruskim crkvenim parohijama u Jugoslaviji predata protojereju Jova-

70 Несиба Палибрк-Сукич, „Санаторий Красного креста Короля-Витязя Александра I Объединителя в городе Панчево“, Вестникъ морского врача, IV, 5, (2008), 127-134; А. Арсењев, Самовари у равници....

${ }^{71}$ Н. Палибрк-Сукич, „Санаторий Красного креста...“, 127-134.

72 Detaljnije o ovoj medicinskoj ustanovi: Александр А. Солонский, Поликлиника Российского общества Красного креста старой организации в Белграде. 1920-1940 (Нови Сад: Штампарија „Натошевић“, 1940), 9-10; Стеван Литвињенко, Руски лекари у Србији и Црној Гори (Београд: Српско лекарско друштво, 2007), 65-72.

${ }^{73}$ С. Литвињенко, н. д., 68-69, 72.

${ }^{74}$ Милана Живанович, „Приют Российского Общества Красного Креста для престарелых, инвалидов и нетрудоспособных в городе Велика-Кикинда“, Ежегодник Дома русского зарубежья имени Александра Солженицына, VII, № 7, (2017), 61-88. 
nu Sokalju, parohu ruskog Hrama Sv. Trojice. Međutim, već dva meseca kasnije, novembra 1944. na molbu parohijskog saveta i članova Episkopskog saveta Ruske zagranične crkve, Srpska crkva je primila Eparhijski savet i starešinu ruske crkve pod svoju zaštitu, čime je poništena odluka Sabora Srpske pravoslavne crkve iz 1921. kojom su ruskoj crkvi data posebna ovlašćenja u zemlji. Ujedno uprava nad ruskim parohijama je poverena episkopu mukačevskoprjaševskom Vladimiru (Rajiću). Ipak, time pitanje ruske crkve nije bilo rešeno. Problem njenog položaja je predstavljao predmet razgovora koji su u Moskvi januara 1945. vodili predstavnici Srpske i Ruske pravoslavne crkve. Budući da je rešenje problema starog srpskog podvorja $u$ Moskvi nađeno $u$ dodeljivanju jedne od moskovskih crkava, po principu reciprociteta trebalo je pristupiti otvaranju podvorja Moskovske patrijaršije u Beogradu odnosno potpadanju ruske crkve u Beogradu pod jurisdikciju Moskovske patrijaršije. ${ }^{75}$ To je ostvareno aprila iste godine - beogradska ruska parohija i Hram sv. Trojice su postali podvorje Moskovske patrijaršije, a oktobra iste godine, patrijarh moskovski i sve Rusije ustrojio je dužnost „Blagočinog nad ruskim pravoslavnim parohijama u Jugoslaviji“" 76

Same ruske parohije i crkvene opštine u zemlji su nastavile rad po završetku vojnih operacija, s tim da se njihov život prilično razlikovao. Pretvaranjem Bolnice-sanatorijuma u Pančevu u bolnicu za lake ranjenike oktobra 1944. iseljen je Hram Sv. Nikolaja Mirlikijskog, koji je bio uređen pri ovoj ustanovi, a ruskim parohijanima je početkom 1945. lokalna crkvena uprava ustupila prostoriju u zgradi svoje škole za dopunsku nastavu veronauke pri Uspenskom hramu. U njoj su Rusi uredili svoju kapelu. Sama parohija je, međutim, bila ukinuta $1967 .{ }^{77}$ Ruska crkva u Sarajevu je bila zatvorena po hapšenju njenog starešine oca Aleksija ubrzo nakon otpočinjanja sovjetsko-jugoslovenskog sukoba, a njena imovina je bila predata Srpskoj crkvi. ${ }^{78}$ Ruska pravoslavna parohija Sv. Vasilija Velikog u Novom Sadu se, pak, ugasila 1955, a zemunska (u Hramu Sv. arhangela Gavrila u parku) 1972. godine. Interesantno je napomenuti da je 1973, usled smanjenja broja vernika, ruski Hram Sv. arhangela Mihaila u Zrenjaninu (u adaptiranim podrumskim prostorijama bivšeg turskog zatvora „Munkač“) odlukom Srpske crkve dodeljen mesnom ženskom manastiru Sv. Melanije. ${ }^{79}$

Paralelno sa pomenutim akcijama preduzimanim prvih poratnih meseci, nove vlasti su sprovodile još jednu koja se ticala grobova Rusa - pripadnika ruskih vojnih emigrantskih organizacija koje su se tokom perioda okupacije i završnih operacija u Jugoslaviji borile protiv partizana odnosno NOVJ-a. Jedna od tih akcija je primenjena u slučaju parcele na Novom groblju u Beogradu. Naime, tokom Drugog svetskog rata na ovom grobnom kompleksu bila je

75 Радмила Радић, Држава и верске заједнице 1945-1970, Том I (Београд: Институт за новију историју Србије, 2002), 246-248.

${ }^{76}$ А. Арсењев, Самовари у равници...

${ }^{77}$ Исто.

78 Ростислав В. Полчанинов, „Русские в Сараеве“, Кадетская перекличка, XXXIV, № 75, (2004), 175.

79 А. Арсењев, Самовари у равници... 
izdvojena posebna parcela - parcela br. 86a radi sahrane vojnika koji su se borili u emigrantskim vojnim jedinicama na teritoriji okupirane Srbije (uglavnom u Ruskom korpusu). Na njoj su sahranjivani borci koji su poginuli u Srbiji i Banatu u periodu od 1942. do 1944. Pogrebe su organizovali Feldkomandantura 599, Ruski korpus ili Nemački štab za vezu kod Ruskog korpusa. Ukupno je na toj parceli počivalo oko 50 boraca. Nakon 1945. ta grobna mesta su prekopana (zvanični razlog je bilo neplaćanje naknade za grobno mesto), a sama parcela je ponovo korišćena. ${ }^{80}$

Isti koraci su bili preduzeti u slučaju vojne parcele na zagrebačkom groblju Mirogoj, specijalno izdvojene tokom Drugog svetskog rata za sahranu lica koja su služila u nemačkoj armiji - većinom pripadnika kozačkih divizija i Ruskog korpusa. Nadgrobni spomenici su uklonjeni, s tim da nije bilo novih sahranjivanja (kao u slučaju beogradskog groblja). ${ }^{81}$ Takođe, uklonjen je nadgrobni spomenik generala Borisa Aleksandroviča Štejfona, koji je bio na čelu Ruskog korpusa od septembra 1941. On je preminuo u Zagrebu aprila 1945. prilikom povlačenja ove formacije, ali je sahranjen na vojnom groblju u Kranju. $^{82}$

Uklanjanje grobova vojnika Ruskog korpusa nije primenjivano u slučaju nekih manjih gradova i varoši. Naime, nekoliko grobnih mesta boraca koji su bili angažovani u ovoj formaciji sačuvano je u Bosni i Hercegovini. ${ }^{83}$

Prvih godina nove vlasti su preduzele još neke akcije, koje su direktno uticale i na druge grobne komplekse ruske emigracije. U sklopu rušenja Starog vojnog groblja u Sarajevu prekopani su i grobovi pitomaca Ruskog kadetskog korpusa na „kadetskoj“ parceli tog kompleksa, čiji su nadgrobnici ružičaste boje bili ukrašeni ordenom Aleksandra Nevskog (koji je predstavljao simboličko obeležje značaka korpusa). ${ }^{84}$ Prema navodima nekadašnjeg kadeta pomenute školske ustanove, Leonida Bujneviča, groblje je trebalo da bude prekopano i demontirano radi širenja gradske bolnice, dok je za ostatke sahranjenih bilo predviđeno da se sakupe i prenesu u zajedničku grobnicu na drugo groblje dale-

${ }^{80}$ Dokumentacija JKP „Pogrebne usluge“ Beograd. Autor se zahvaljuje dr Violeti Obrenović na informaciji.

${ }^{81}$ T. Puškadija-Ribkin, $n$. d., 183.

${ }^{82}$ Русский Корпус на Балканах..., 353; Franc Benedik, „Nemško vojaško pokopališče v Kranju“, v: Kranjski zbornik (Kranj: Mestna občina, 2000), 250-259; Darko Cafuta, „Nemško pokopališče v Kranju“, v: Nemci in partizani. Nemške izgube na Gorenjskem med miti in resnico, ur. Jože Dežman (Kranj: Gorenjski muzej, 2016), 51.

${ }^{83} \mathrm{U}$ jednom dokumentu iz šezdesetih godina pominje se da je i na groblju u Celju bilo sahranjeno oko 30 Rusa koji su se borili u redovima nemačke armije. AJ, fond 606, Sekretarijat SIV-a za socijalnu politiku i komunalna pitanja, fascikla 53, 1961, Poverljiva arhiva 1-123, Ivan Železnikar - Sekretarijatu SIV-a za socijalnu politiku i komunalna pitanja.

${ }^{84}$ Značke korpusa su bile ružičaste boje, boje ordena kneza Aleksandra Nevskog. Imale su oblik krsta sa raširenim kracima u kojima su se nalazila slova R. K. K. (slova su označavala Ruski kadetski korpus). U centru krsta je bio medaljon u kojem su bile predstavljene tri epolete crvena koja je simbolisala Polocki kadetski korpus, plava - Odeski i bela - Vladimirski Kijevski. Značke su ustanovljene 1926. godine. Александр В. Окороков, Знаки русской эмиграции (1920-1990) (Москва: Collector's Book, 2005), 127, 170. 
ko od grada. ${ }^{85}$ Prema drugim informacijama, na tom mestu su izgrađena dva zdanja, od kojih je jedno bilo Arhitektonski fakultet, s tim da su Rusima predložili da kosti članova svojih porodica i poznanika prenesu na periferiju grada. ${ }^{86}$ Zabeležena je još jedna verzija u vezi sa presahranjivanjem tih zemnih ostataka. Prema njoj, ruske izbeglice, žitelji grada, tajno su preneli pronađene kosti preminulih na jedno groblje van Sarajeva. ${ }^{87}$ Ostaci pokojnika su bili sakupljeni u zajedničku grobnicu i sahranjeni u obližnjoj varoši ${ }^{88}$ Nad grobnicom je podignut masivan kameni spomenik sa crnom mermernom pločom na kojoj je bilo uklesano „Gospode, upokoji njihove duše““. ${ }^{89}$

Istovremeno, treba istaći da su sačuvani spomenici ruskim emigrantima podizani u međuratnom periodu u nekolicini mesta u zemlji. Sačuvan je spomenik u selu Korbevac, u blizini Vranja, posvećen kubanskim kozacima - emigrantima, koji su preminuli u ovom mestu gradeći u periodu od 1921. do 1925. put VranjeBosilegrad, takozvani „ruski put“. Ovo obeležje, visine 5 metara, imalo je formu zasečene piramide na čijem vrhu se nalazio krst. Na njemu je bio natpis: „Kubanska kozačka divizija - braći kozacima koji su umrli u izgnanstvu 1921-1925“.90 Nedaleko od ovog, u selu Besna Kobila, u blizini grobova kozaka, bio je postavljen još jedan memorijal u formi obeliska kubanskim kozacima ${ }^{91}$ Sačuvan je i spomenik-obelisk na Vojnom (sadašnjem Gradskom) groblju u Herceg Novom podignut 1931. Ovaj memorijal u vidu zarubljene piramide visine $3,8 \mathrm{~m}$, na čijem vrhu se nalazio krst visine $80 \mathrm{~cm}$, bio je posvećen „Ruskim ljudima, koji su izgubili Otadžbinu, i koji su pronašli večni pokoj u bratskoj zemlji“. ${ }^{92}$

Izvesne, pak, izmene izvedene su na memorijalu podignutom na gradskom pravoslavnom groblju u Vršcu 1927. godine. Ovaj obelisk, postavljen na inicijativu lokalnog odseka Saveza ruskih oficira, i sredstvima ove organizacije i ruske kolonije, bio je posvećen „Oficirima i vojnicima ruske carske armije i Rusima koji su ovde sahranjeni“, ali je kasnije ovom obeležju dat drugačiji smisao. Naime, s ciljem očuvanja imena preminulih emigranata čiji su grobovi bili obeleženi samo drvenim krstovima, ona su klesana na pomenuti spome-

85 Леонид Буйневич, „Последний привет с кадетского кладбища“, Кадетская перекличка, VIII, № 17, (1978), 103.

${ }^{86}$ Р. Полчанинов, op. cit., 175-176.

87 Анатолий М. Росселевич, Кадетские корпуса за рубежом. 1920-1945 (Нью-Йорк: Объединение кадет российских зарубежных кадетских корпусов, 1970), 410-411.

${ }^{88}$ Prema navodima Rostislava Polčaninova, žitelja Sarajeva, u jednoj grobnici je bio sahranjen direktor korpusa, general-lajtnant Boris Adamovič, u drugoj, zajedničkoj grobnici - kadeti, a u trećoj, takođe zajedničkoj grobnici - ostali Rusi. Р. Полчанинов, op. cit., 175-176.

89 Алексей Б. Арсеньев, „Русская эмиграция в Боснии и Герцеговине (1919-1990-е гг.)“, Ежегодник Дома русского зарубежья имени Александра Солженищына, I, № 1, (2011), 159.

${ }^{90}$ Мирослав Јовановић, „’Херој је мртав - идеја је бесмртна': Симболика смрти и погребних ритуала у избеглиштву (Пример Руског избеглиштва на Балкану)“, Годишъак за друштвену историју, XIV, бр. 1-3, (2007), 55.

91 Архив внешней политики Российской Федерации, фонд 202, Посольство в Югославии, опись 52, дело 5, папка 230, лист 18.

92 Борис Р. Дабовић, „Руско гробље у Херцег Новом“, Бока. Зборник радова из науке, културе и умјетности, XIX, 21-22, (1999), 285. 
nik. Usled ograničenosti prostora, na obelisku su bila ispisana samo 52 imena. Memorijal je bio ukrašen znamenjem imperatorske Rusije - dvoglavim orlom. On je uništen po okončanju Drugog svetskog rata, pa je postavljeno novo obeležje - krst. $^{93}$

Očuvano je bilo i grobno mesto poslednjeg glavnokomandujućeg ruske carske armije (iz Februarske revolucije) generala Mihaila Vasiljeviča Aleksejeva na Novom groblju u Beogradu (van ruske parcele). General Aleksejev, koji je bio i inicijator osnivanja Dobrovoljačke armije, preminuo je u Jekaterinodaru oktobra 1918. i potom u tom gradu sahranjen. Međutim, usled sve izvesnijeg poraza antiboljševičkih snaga u Građanskom ratu u Rusiji i shodno tome evakuacije pripadnika Belog pokreta i protivnika revolucionarnih vlasti, porodica Aleksejeva je, ne hoteći da ostavi njegove kosti u zemlji u kojoj su boljševici na vlasti, iskopala sanduk sa njegovim zemnim ostacima. Po dolasku u Beograd, oni su sahranjeni na Novom groblju. ${ }^{94}$ Grobno mesto je bilo obeleženo samo krstom od belog mermera na kojem je bilo urezano ime Mihail. $^{95}$

I grobno mesto poslednjeg glavnokomandujućeg Dobrovoljačke armije, generala Petra Nikolajeviča Vrangela, sahranjenog 1929. u ruskoj crkvi u Beogradu, bilo je sačuvano. Vrangel je preminuo u Briselu 1928. godine, s željom da njegove kosti počivaju u pomenutom Hramu Sv. Trojice „u senci ruskih ratnih simbola i barjaka koji su se čuvali u njoj““. ${ }^{96}$ Njegova želja je ostvarena oktobra 1929. godine. U crkvi je izgrađena specijalna masivna mermerna grobnica za pokojnika na kojoj je bilo uklesano: „Ovu ikonu su izradili ruski ljudi u rasejanju, u spomen na ovde sahranjenog Glavnokomandujućeg ruske armije, generala barona Petra Nikolajeviča Vrangela do povratka u rodnu zemlju“".97 Dolaskom Komunističke partije na vlast u Jugoslaviji, starešina ruske crkve je prikrio Vrangelov grob slikom-ikonom „Pilatov Sud“ i privezao je metalnom žicom za zid. Grob je ostao sakriven sve do 1957, odnosno dolaska patrijarha moskovskog i sve Rusije Aleksija I u Beograd. Prilikom posete crkvi, naredio je da se ikona podigne. Tada je i otkriven grob. ${ }^{98}$

\footnotetext{
93 Александр А. Рогаткин, „Русская колония в Вршаце“, в: Русские в Сербии. Взаимоотношения России и Сербии с кониа ХІІ до начала ХХ века. Русская эмиграция в Сербии. Россияне в Сербии - последних 60 лет и сегодня, составители Алексей Ю. Тимофеев и Алексей Б. Арсеньев (Белград: Весна инфо: Координационный совет российских соотечественников в Сербии, 2009), 194; И. Л., „За рубежомъ“, Возрождение, 13. 7. 1927, 3; С. Ильяшенко, „Памятникь“, Русский военный вестник, 10. 7. 1927, 2.

94 М. Јовановић, „’Херој је мртав - идеја је бесмртна'...“, 56. Detaljnije o sahrani: МА Милана Живановић, „Руски гробни комплекси у Србији у 20. веку“ (докторска дисертација, Универзитет у Београду, Филозофски факултет, Одељење за историју, 2019), 190-193.

${ }^{95}$ М. Живановић, „Руски гробни комплекси...“, 190.

${ }^{96}$ Cit. prema: М. Јовановић, ,'Херој је мртав - идеја је бесмртна'...“, 56.

${ }^{97}$ М. Живановић, „Руски гробни комплекси...“, 195-201.

98 Павел Пагануцци, „Генерал барон П. Н. Врангель. К 100-летию со дня рождения и к 50тилетию со дня смерти - 1878-1928-1978“, Кадетская перекличка, VIII, № 19, (1978), 29-30.
} 


\section{Zaključak}

Približavanje Crvene armije granicama predratne Jugoslavije i zajedničke operacije dve armije imali su direktne posledice po život i sudbinu ruske emigracije i njenog nasleđa. Školske i muzejske ustanove su prestale da postoje u jesen 1944. godine, s tim da su pojedine zdravstvene nastavile svoju delatnost do 1945/1946. Mnogi predmeti iz muzejskih zbirki su uništeni (iako su izvesne dragocenosti poput pojedinih ikona i zastava iznete iz zemlje od strane samih emigranta, koji su je napustili pre dolaska Crvene armije u njihova mesta), uklanjani su nadgrobni spomenici. Slika odnosa Crvene armije i Komunističke partije Jugoslavije prema nasleđu ruske emigracije, međutim, nije bila jednodimenzionalna. Naime, očuvane su ruske zastave, izvestan broj predmeta iz muzejskih kolekcija, delovi knjižnih fondova ruskih biblioteka i grobna mesta značajnih predstavnika Belog pokreta, dok su arhive mnogih ustanova odnete u SSSR i predate odgovarajućim ustanovama na čuvanje. Ovaj odnos je moguće ilustrovati i preko citata prvog koji je zabeležio jedan sovjetski kapetan koji se februara 1945. upisao u knjigu poseta Spomenika Ruske slave na Novom groblju u Beogradu: „Ja sam oficir Crvene armije, ali sam vaspitan u pravoslavlju i ljubavi prema ruskom čoveku“, ${ }^{99}$ i drugog koji je posle Drugog svetskog rata izgovorio u šaljivom tonu pozorišni reditelj Jurij Rakitin upirući prstom ka zvezdi petokraki postavljenoj na kuli nekadašnje palate Dunavske banovine u Novom Sadu: „Celog života bežao sam od ove crvene petokrake i, konačno, ovde me je stigla“. $1{ }^{100}$

${ }^{99}$ Cit. prema: В. Маевский, op. cit., 46.

${ }^{100}$ Cit. prema: А. Б. Арсеньев, У излучины Дуная.... 


\section{REFERENCE}

- Arsen'ev Aleksej B., i Mixail L. Ordovskij-Tanaevskij. Gimnaziya v licax. Pervaya russko-serbskaya gimnaziya v Belgrade (1920-1944). T. 1. Belgrad: Arxiv Serbskoj Pravoslavnoj Cerkvi, 2018.

- Arsen'ev, Aleksej B. „Kul'turnye organizacii russkoj intelligencii v Yugoslavii 1920-1940 gg.“. V: Blokovskij sbornik, 309-335. Tartu: Tartu Ülikooli Kirjastus, 1996.

- Arsen'ev, Aleksej B. „Lyudi i knigi: sem'ya Malininyx i ix biblioteka“. V: Russkoe zarubezh'e i slavyanskij mir. Sbornik trudov. Sostavitel' Petr Bunyak, 206-223. Belgrad: Slavisticheskoe obshhestvo Serbii, 2013.

- Arsen'ev, Aleksej B. „Russkaya ehmigraciya v Bosnii i Gercegovine (19191990-e gg.)“. Ezhegodnik Doma russkogo zarubezh'ya imeni Aleksandra Solzhenicyna, I, № 1, (2011), 140-169.

- Arsen'ev, Aleksej B. U izluchiny Dunaya: Ocherki zhizni $i$ deyatel'nosti russkix v Novom Sadu. Moskva: Russkij put', 1995.

- Arsenjev, Aleksej. „Rusi u Banatu“. U: Banat kroz vekove. Slojevi kultura Banata: Zbornik radova, urednik Miodrag Maticki, 663-712. Beograd: Vukova zadužbina, 2010.

- Arsenjev, Aleksej. Samovari u ravnici. Ruska emigracija u Vojvodini. Novi Sad: Zmaj; Futog: Umetnička radionica Zaveštanje, 2011.

- Benedik, Franc. „Nemško vojaško pokopališče v Kranju“. V: Kranjski zbornik, 250-259. Kranj: Mestna občina, 2000.

- Bilimovich, Aleksandr D. Russkaya matica. Lyublyana: Russkoj maticy, 1924.

- Bujnevich, Leonid. „Poslednij privet s kadetskogo kladbishha“. Kadetskaya pereklichka, VIII, № 17, (1978), 85-103.

- Cafuta, Darko. „Nemško pokopališče v Kranju“. V: Nemci in partizani. Nemške izgube na Gorenjskem med miti in resnico, ur. Jože Dežman. Kranj: Gorenjski muzej, 2016.

- Dabić, Ljubica. „Rusko odeljenje u Vojnom muzeju u Beogradu 1936-1941“. Zbornik Istorijskog muzeja Srbije, XXXI, br. 31, (2003), 329-346.

- Dabović, Boris R. „Rusko groblje u Herceg Novom“. Boka. Zbornik radova iz nauke, kulture i umjetnosti, XIX, br. 21-22 (1999), 283-290.

- Danilov, V. S. „Ehvakuaciya russkoj beloj ehmigracii iz Yugoslavii“. Kadetskaya pereklichka, XI, № 28, (1981), 87-94.

- Dimić Ljubodrag, i Miladin Milošević, prir. Jugoslovensko-sovjetski odnosi 1945-1956: zbornik dokumenata. Beograd: Ministarstvo spoljnih poslova, 2010.

- Dimić, Ljubodrag. „Rusko školstvo u Kraljevini Jugoslaviji 1918-1941“. U: Ruska emigracija u srpskoj kulturi XX veka: zbornik radova, T. 2. Urednici Miodrag Sibinović, Marija Mežinski i Aleksej Arsenjev, 38-51. Beograd: Filološki fakultet, Katedra za slavistiku i Centar za naučni rad, 1994.

- Drobashevskij, Vitalij P. „Spravka o Muzee russkoj konnicy v g. Belgrade“. V: Xranilishha pamyatnikov kul'tury i istorii Zarubezhnoj Rusi. Redaktor N. 
A. Slobodchikov, 97-98. San-Francisko: Muzej Russkoj Kul'tury v SanFrancisko, 1966.

- Đurić, Ostoja. Ruska literarna Srbija 1920-1941: pisci, kružoci, izdanja. Gornji Milanovac: Dečje novine, 1990.

- Đurić, Ostoja. „Šezdeset godina Ruskog doma Imperatora Nikolaja II u Beogradu (1933-1993)“. U: Ruska emigracija u srpskoj kulturi XX veka: zbornik radova, knj. I. Urednici Miodrag Sibinović, Marija Mežinski i Aleksej Arsenjev, 123-128. Beograd: Filološki fakultet, Katedra za slavistiku i Centar za naučni rad, 1994.

- Yoxina, Nataliya A. , 'Istoriya russkogo Soprotivleniya... eshhe ne napisana' $\mathrm{K}$ istorii Soyuza sovetskix patriotov v Yugoslavii v gody Vtoroj mirovoj vojny“. Ezhegodnik Doma russkogo zarubezh'ya imeni Aleksandra Solzhenicyna, IV, № 4-5(2014-2015), 174-205.

- Yoxina, Nataliya A. ,'Na ch'ej storone ty budesh', kogda razrazitsya vojna': K istorii Soyuza sovetskix patriotov v Belgrade“. V: Rossijskaya ehmigraciya v bor'be s fashizmom. Mezhdunarodnaya nauchnaya konferenciya. Sostavitel' Konstantin K. Semenov, 203-237. Moskva: Dom russkogo zarubezh'ya im. Aleksandra Solzhenicyna, 2015.

- Falaleeva, M. V. „Fond Romanovyx v sobranii OPI GMI“. V: Arxeograficheskij ezhegodnik za 1996 g. Redaktor Sigurd O. Shmidt, 270-281. Moskva: Nauka, 1998.

- Gudkov, Vladimir P. „Chetyre desyatiletiya obshheniya i druzhby. Yugoslavyanskaya istoriya v novoe i novejshee vremya“. V: Materialy nauchnyx chtenij, posvyashhennyx 80-letiyu so dnya rozhdeniya prof. $V$. G. Karaseva (1922-1991), 258-259. Moskva: Izdatel'stvo Moskovskogo universiteta, 2002.

- Gurkovskij, Vladlen A. Rossijskie kadetskie korpusa za rubezhom. Moskva: Belyj Bereg, 2009.

- Il'yashenko, S. „Pamyatnik"“. Russkij voennyj vestnik, 10. 7. 1927, 2.

- Iz dnevnikov atamana $V$. G. Naumenko s kommentariyami N. V. Nazarenko. Krasnodar: KGUKI, 2000.

- Jovanović, Miroslav. Doseljavanje ruskih izbeglica u Kraljevinu SHS 19191924. Beograd: Stubovi kulture, 1996.

- Jovanović, Miroslav. „, 'Heroj je mrtav - ideja je besmrtna': Simbolika smrti i pogrebnih rituala u izbeglištvu (Primer Ruskog izbeglištva na Balkanu)“. Godišnjak za društvenu istoriju, XIV, br. 1-3, (2007), 47-60.

- Jovanović, Miroslav. Ruska emigracija na Balkanu (1920-1940). Beograd: Čigoja, 2006.

- Jovanović, Miroslav. „Ruska pravoslavna zagranična crkva u Jugoslaviji tokom dvadesetih i tridesetih godina 20. veka“. U: Srpska teologija u dvadesetom veku - istraživački problemi i rezultati: zbornik radova naučnog skupa 3. Priredio Bogoljub Šijaković, 160-178. Beograd: Pravoslavni bogoslovski fakultet, 2008. 
- Jovanović, Miroslav. „Sveštenik i društvo: eto parole“ - Ruska pravoslavna zagranična crkva na Balkanu 1920-1940“. Tokovi istorije, XIII, br. 3-4, (2005), 67-100.

- Kačaki, Jovan. Ruske izbeglice u Kraljevini SHS/Jugoslaviji. Bibliografija radova 1920-1944: pokušaj rekonstrukcije. Beograd: Knjižara Žagor; Univerzitetska biblioteka, 2003.

- Korsakova, Natal'ya A. „Dnevniki atamana Kubanskogo kazachestva v Zarubezh'e V. G. Naumenko kak istochnik o sud'be kubanskix vojskovyx regalij“. V: Zarubezhnaya Rossiya. 1917-1939 gg.: Sbornik statej, 86-90. SanktPeterburg: Liki Rossii, 2000.

- Kosik, Viktor I. „Russkaya cerkov' v Yugoslavii 1921-1939 gody“. Slavyanovedenie, XXXII, № 6, (1996), 66-76.

- Kotyukov, Konstantin L. „Formirovanie i boevaya deyatel'nost' Russkogo oxrannogo korpusa v Yugoslavii v 1941-1945 gg.“. Otechestvennaya istoriya, LII, № 3, (2008), 86-94.

- Kovan'ko, G. A. „Uzhin v Moskve“. Kadetskaya pereklichka, XXI, № 48, (1990), 61-63.

- Kurganskij, V. „Tridcat' let tomu nazad“. Kadetskaya pereklichka, IV, № 11, (1975), 55-64.

- Lažetić, Predrag. Vojni muzej: 1878-2014. Beograd: Medija centar „Odbrana“, 2014.

- L., I. „Za rubezhom"“. Vozrozhdenie, 13. 7. 1927, 3.

- Litvinjenko, Stevan. Ruski lekari u Srbiji i Crnoj Gori. Beograd: Srpsko lekarsko društvo, 2007.

- Maevskij, Vladislav A. Russkie v Yugoslavii: Vzaimootnosheniya Rossii $i$ Serbii. T. 2. N'yu-Jork: Ist. kruzhok, 1966.

- Muzej za uspomenu na Cara Nikolu II: Katalog. Beograd: Društvo za uspomenu na Cara Nikolu II, 1936.

- Okorokov, Aleksandr V. Znaki russkoj ehmigracii (1920-1990). Moskva: Collector's Book, 2005.

- Opis' muzeya s otdelami: general Vrangel', Russkij voennyj, rossijskie kadetskie korpusa i voennyya uchilishha, zarubezhnyya voenno-uchebnyya organizaci. Belaya Cerkov': Velikogo Knyazya Konstantina Konstantinovicha kadetskij korpus, 1933.

- Paganucci, Pavel. „General baron P. N. Vrangel'. K 100-letiyu so dnya rozhdeniya i k 50-tiletiyu so dnya smerti - 1878-1928-1978“. Kadetskaya pereklichka, VIII, № 19, (1978), 6-31.

- Palibrk-Sukich, Nesiba. „Biblioteka russkoj kolonii v Gorodskoj biblioteke goroda Panchevo". V: Russkaya diaspora $i$ izuchenie russkogo yazyka $i$ russkoj kul'tury $v$ inoslavyanskom i inostrannom okruzhenii. Redaktor Bogolyub Stankovich, 239-246. Belgrad: Slavistichko drushtvo Srbije, 2012.

- Palibrk-Sukich, Nesiba. „Sanatorij Krasnogo kresta Korolya-Vityazya Aleksandra I Ob"edinitelya v gorode Panchevo“. Vestnik" morskogo vracha, IV, № 5, (2008), 127-134. 
- Pavlović Momčilo, i Toma Milenković, prir. Beloemigracija u Jugoslaviji 1918-1941, Tom I. Beograd: Institut za savremenu istoriju, 2006.

- Pejović, Marko. „Odnosi Društva za kulturnu saradnju Jugoslavija-SSSR i Svesaveznog društva za kulturne veze sa inostranstvom 1945-1948“. Magistarski rad, Univerzitet u Beogradu, Filozofski fakultet, Odeljenje za istoriju, 2010.

- Polchaninov, Rostislav V. „Russkie v Saraeve“. Kadetskaya pereklichka, XXXIV, № 75, (2004), 172-177.

- Prosen, Milan. „75 godina Ruskog doma u Beogradu“. Nasleđe, IX, br. 9, (2008), 211-220.

- Puškadija-Ribkin, Tatjana. Emigranti iz Rusije u kulturnom $i$ znanstvenom životu Zagreba. Zagreb: Prosvjeta, 2006.

- Puzović, Vladislav. „Ruska zagranična crkva u periodu između dva svetska rata: pregled literature u Srbiji“. U: Srpska teologija danas 2009 - zbornik radova prvog godišnjeg simposiona održanog na Pravoslavnom bogoslovskom fakultetu 29-30. maja 2009, priredio Bogoljub Šijaković, 386-391. Beograd: Pravoslavni bogoslovski fakultet- Institut za teološka istraživanja, 2010.

- Radić, Radmila. Država i verske zajednice 1945-1970, I tom. Beograd: Institut za noviju istoriju Srbije, 2002.

- Ramadanski, Draginja. „Biblioteka kolonije ruskih izbeglica u Senti“. U: Ruska emigracija u srpskoj kulturi XX veka: zbornik radova, knj. II. Urednici Miodrag Sibinović, Marija Mežinski i Aleksej Arsenjev, 42-48. Beograd: Filološki fakultet, Katedra za slavistiku i Centar za naučni rad, 1994.

- Rosselevich, Anatolij M. Kadetskie korpusa za rubezhom 1920-1945. N'yuJork: Ob"edinenie kadet rossijskix zarubezhnyx kadetskix korpusov, 1970.

- Ruska emigracija u srpskoj kulturi XX veka: zbornik radova, knj. I-II, urednici Miodrag Sibinović, Marija Mežinski i Aleksej Arsenjev. Beograd: Filološki fakultet, Katedra za slavistiku i Centar za naučni rad, 1994.

- Russkaya matica (1924-1934): Otchet o deyatel'nosti. Lyublyana: Russkaya matica, 1935.

- Russkaya voennaya ehmigraciya 20-x - 40-x godov. Dokumenty i materialy. Tom II. Moskva: Triada-X, 2001.

- Russkij kadetskij korpus. Kadetskaya pamyatka 1920-1925. Vtoroj sbornik Konstantinovskago kruzhka. Saraevo: Russkij kadetskij korpus, 1925.

- Russkij Korpus na Balkanax vo vremya II Velikoj vojny 1941-1945 gg. Istoricheskij ocherk $i$ sbornik vospominaniya soratnikov. N'yu-Jork: Nashi vesti, 1963.

- Sed'maya kadetskaya pamyatka. Yubilejnaya. 1920-1995. N'yu-Jork: Izdatel'stvo Ob"edineniya kadet Rossijskix kkadetskix korpusov, 1997.

- Semenov, Konstantin K. „Svyatyni Russkoj armii v xrame Svyatoj Troicy v Belgrade (1924-1944 gg.) g.“. Ezhegodnik Doma russkogo zarubezh'ya imeni Aleksandra Solzhenicyna, VII, № 7, (2017), 89-113.

- Solonskij, Aleksandr A. Poliklinika Rossijskogo obshhestva Krasnogo kresta staroj organizacii v Belgrade. 1920-1940. Novi Sad: Shtamparija „Natosheviћ“, 1940. 
- Sorokina, Marina Yu. „Peresekaya granicy: rossijskie uchenye-ehmigranty chleny Serbskoj akademii nauki i iskusstv“. V: Russkaya diaspora $i$ izuchenie russkogo yazyka i russkoj kul'tury $v$ inoslavyanskom i inostrannom okruzhenii. Redaktor Bogolyub Stankovich, 69-77. Belgrad: Slavistichko drushtvo Srbije, 2012.

- Shevyakov Timofej N. i Oleg Parxaev. Znamena i shtandarty Rossijskoj imperatorskoj armiikonca XIX-nachala XXv. Moskva: AST, Astrel', 2002.

- Timofeev, Aleksej Yu. „Slomannye sud'by. 1948-1953 gg. Repressii pervogo poslevoennogo desyatiletiya protiv russkoj ehmigracii v Yugoslavii (po materialam Upravleniya Gosudarstvennoj bezopasnosti)“. Ezhegodnik Doma russkogo zarubezh'ya im. Aleksandra Solzhenicyna, IX, № 9, (2019), 292-309.

- Timofejev, Aleksej, prir. Crvena armija i ruska emigracija u Jugoslaviji za vreme Drugog svetskog rata u ogledalu anti IB-ovske propagande. Beograd: Centar za izučavanje Tradicije Ukronija, 2018.

- Timofejev, Aleksej. Rusi i Drugi svetski rat u Jugoslaviji. Uticaj SSSR-a $i$ ruskih emigranata na događaje u Jugoslaviji 1941-1945. Beograd: Institut za noviju istoriju Srbije, 2011.

- Timofejev, Aleksej. „Savez sovjetskih patriota - antifašistička organizacija ruskih emigranata u Srbiji 1941-1945“. Tokovi istorije, XX, br. 3, (2012), 257-277. https://doi.org/10.31212/tokovi.2012.3.tim.257-277

- Zhivanovich, Milana. „Molot v rukax krasnyx: sud'ba Russkogo doma posle 1944 g.“. Ezhegodnik Doma russkogo zarubezh'ya imeni Aleksandra Solzhenicyna, IX, № 9, (2019), 353-369.

- Zhivanovich, Milana. „Priyut Rossijskogo Obshhestva Krasnogo Kresta dlya prestarelyx, invalidov i netrudosposobnyx v gorode Velika-Kikinda“. Ezhegodnik Doma russkogo zarubezh'ya imeni Aleksandra Solzhenicyna, VII, № 7, (2017), 61-88.

- Živanović, Milana. „Politika sećanja u Jugoslaviji na oslobodilačke operacije 1944. i ulogu Crvene armije“. Tokovi istorije, XXVIII, br. 2, (2020), 139-160. https://doi.org/10.31212/tokovi.2020.2.ziv.139-160

- Živanović, MA Milana. „Ruski grobni kompleksi u Srbiji u 20. veku“. Doktorska disertacija, Univerzitet u Beogradu, Filozofski fakultet, Odeljenje za istoriju, 2019. 
MILANA ŽIVANOVIĆ, PhD, Research Associate

Institute for Recent History of Serbia

Belgrade, Republic of Serbia

milana.zivanovic@yahoo.com

\section{THE FATE OF THE HERITAGE OF THE RUSSIAN EMIGRATION IN YUGOSLAVIA IN 1944-1945}

\section{Summary}

The arrival of the Red Army at the borders of the former Kingdom of Yugoslavia in the autumn of 1944 led to a mass evacuation of Russian émigrés. According to an analysis made by a researcher of the history of the Russian Emigration, around $60 \%$ of the Russian inhabitants in Belgrade fled the capital. Those of Russian origin who stayed in the country were treated in different ways by the NKVD, the Red Army soldiers, and the new revolutionary authorities. So, the level of impact that the arrival of the Red Army, liberation operations, and the seizure of power by the Communist Party of Yugoslavia had on the heritage of the Russian Emigration in Yugoslavia - institutes, which the émigré communities had formed in the interwar period, as well as the different aspects of Russian culture and forms of their presence in the state, varied. Some of the regalia, museum exhibits, and archives were transferred to the USSR, one part was destroyed by the Soviet command, while others were saved in one way or another. The graves of the members of the Russian corps on the cemeteries in Belgrade and Zagreb were dismantled by the new revolutionary authorities, but the monuments dedicated to the Russian émigrés who died in Yugoslavia in the interwar period were kept. Due to the mass evacuation in the autumn of 1944, the vast majority of the Russian institutes stopped working, but on the other hand, some of them, like the Russian parishes, continued with their activities until the 1970s.

KEYWORDS: Russian Emigration, Yugoslavia, Heritage, Museums, Libraries, Archives, Burial Complexes 